The species may be known as CRAspedaCUsta SOWERBII, nov. gen. et sp.-I name the species in honour of $\mathrm{Mr}$. Sowerby, who discovered it, and to whose quick observation and courteous kindness zoologists are indebted for the knowledge of this interesting animal.

The sole character which I can give as specific over and above the generic characters summarised above is that of size. The diameter of the disk does not exceed one-third of an inch.

Locality.-The water-lily tank in the gardens of the Botanical Society, Regent's Park, London.

Very abundant during June, i880. Probably introduced from the West Indies.

E. RAY LANKESTER

\section{NOTES FROM FAVA}

$\mathrm{T}$

$\mathrm{HE}$ following extracts from a letter written from Java by Mr. Henry O. Forbes to Mr. H. N. Moseley, F.R.S., have been sent to us for publication as of consi-
derable interest. The letter is dated March I9. Mr. Forbes, who has been engaged in collecting in Java, expects shortly to leave for Celebes, Timor, Timor-laut, and other eastern islands. Timor-laut is the most important island of the Malay Archipelago yet remaining to be explored, and is likely to yield many natural history treasures. Mr. Forbes's letter refers to certain passages in Mr. Moseley's "Notes by a Naturalist on the Challenger." The question of the mode of growth of Myrmecodia and Hydrophytum has been lately before the Linnean Society.

"With regard to birds carrying seeds from one island to another, I have observed on the Cocos Keeling Islands (South Indian Ocean) a species of heron which nested in a high tree (species unknown) there, quite covered with its oblong hooked seeds. I was informed by the proprietor of the island that many of these birds, from their feathers getting so thickly covered with the seeds, actually die. I can therefore imagine that many of these seeds might adhere for even weeks and months, and so get transported to very distant regions.

"At p. 493 you note the habit of hot-water drinking. It is quite a custom among, at any rate, the Sudanese, among whom I have been living some time, who, in the afternoons, invite each other to come and have a cup of hot water. It is drunk either plain or with a little arenga sugar.

"I have found here a large quantity of algæ growing in the hot springs at a temperature of $132^{\circ} \mathrm{F}$. What the species are or is I have not yet ascertained.

"With reference to Myrmecodia and Hydnophytum, I find some difficulty in reconciling in all cases the statement (p. 389) that 'the ants gnaw at the base of the stem, and the irritation produced causes the stem to swell,' with what I have myself observed. I have grown many young seedlings, some of which were entirely unmolested by ants, and yet produced a bulbous swelling at the base; others were certainly scratched, but that was all, by the ants, the smallest scar being visible. On opening many of those which were unmolested I observed a degenerated, soft, spongy portion, not in connection with the exterior. May not this spot increase till an external opening is formed, and the ants have an entrance made for them to carry out, as I have seen them doing, the soft spongy substance inside? I have seen other secdlings that had a small orifice close to the rootlet, leading into an interior oval or round expansion in the bulb, and though I closely observed them I failed to detect ants touching them. All these seedlings I grew from the seed till they reached at most a couple or three inches or a little more, when they generally became the home of some ants. After they had become infeste 1 I did not pursue observations on them, as my time was much occupied, and because the object of my observation was to discover if they bulbed, \&c., without the aid of ants. I should much like to see these plants grow with all ant life removed from them entirely. If opportunity again offers I shall continue my experiments. I have repeatedly noticed on large Myrmecodia and Hydnophyta which were crowded with ants (on both genera I have found only one species of ant) that in many places irregularlyshaped areas of degeneration existed quite cut off from communication with the wonderful series of galleries and chambers which form this ant-hive. These were found oftenest near the upper portion of the bulb, and towards which excavations were being directed. I have not. observed that the surface of the rounded mass gives off any twigs bearing leaves or flowers. All my specimens have had the shape of a bulb more or less gobose, or elongate, prickly, tenanted by ants, giving origin to a much thinner stem, not, or rarely, chambered nor passaged, but also armed, and from which the leaves and sessile flowers proceeded, the latter from hollows in which numerous ants were constantly moving about. The Hydnophyta generally give off at once leaves at the summit of a more or less irregular bulb.

"I have seen the same species of ant inhabiting the swollen-up hollow leaves of a species of Hoya or Eschynanthus. The plant I saw had many of its leaves in this condition. I gathered it one day while on the march, and I fear it is lost. It may have been sent to the British Museum, but I am not certain. I have not met with another instance. There was a small hole in the apex of the lcaf, and through it the ants came and went. The leaf looked as if all the mesophyllum had been cleared out and the epidermis blown out into a bladder. This observation may not be quite accurate as to the description of leaf, but I noted that the species of ant was the same.

"Here it is quite impossible to obtain a perfect rhinoceros skull, unless one has the good fortune to shoot it oneself, for the horn is so highly prized that it alone fetches from 200 to 300 rupees (Dutch guelders), being eagerly bought by the Chinese. It is believed in by all the natives as a sure and certain antidote for snake-bites and for purifying water. A respectable hadji affirmed to me with the persistency of belief that on his way to Mecca -he went in a native vessel-the stock of fresh water on board ran out, and that all on the vessel, by drinking sea-water out of a rhinoceros horn, found it to be--not salt water!"

\section{ON THE FERTILISATION OF COBAEA PENDULIFLORA (HOOK. FIL.)}

COBAEA PENDULIFLORA is a graceful climber, growing rather sparingly in our mountain-forests. It was described and figured by Karsten under the name of Rosenbergia penduliflora ("Flora.Columbix," I. 27, t. ix.), and afterwards in the Bot. Mag., i. 5757. Karsten's plate is very pretty, but in all the specimens $I$ have seen the linear lobes of the corolla were never so red as he paints them, nor do the stamens ever hang straight downwards parallel to the style, as his figure shows. The plate in the Botanical Magazine has only one defect, the artist having overlooked the hooklets and the ends of the tendrils.

The plant grows exceedingly quickly when kept in shade. A specimen now in my garden was raised from seed sown October 3, 1879, which sprang up a fortnight later, and covered, in less than three months, a wall twelve feet high and ten feet long. It climbs exactly in the same manner as Cobaea scandens, described by Darwin in his "Climbing Plants." The flowers have very little to attract attention, their colour being dull green, with very little red on the filaments, and there is no smell. Though not of great horticultural interest, the plant fully deserves the attention of the botanist on account of the peculiar circumstances under which the flowers are fertilised. Sir J. D. Hooker has made already some pertinent remarks on 
this point in his description in the Bot. Mag., and it was for the further investigation of the case that I raised a plant in my garden.

The flowers grow on long peduncles, which generally have a horizontal position, projecting some five or six inches from the mass of the foliage. When the calyx opens, the filaments as well as the style are irregularly twisted; but in about two or three days all become straight. The style hangs obliquely downwards; the filaments all bend sideways, the bend being inside the tube of the corolla, a little over the hairs at their base. There is often a distance of 15 centimetres between the anthers of either side. About 5 or 6 o' clock p.m. the anthers burst, and soon after the style rises and assumes a central position, so that there is a distance of about ro centimetres between the stigmata and any of the anthers. Only then is nectar being secreted by the glandular disk round the base of the ovary, but so copiously that by means of a small pipette I obtained from cach flower a mean quantity of $0^{\circ} 14$ cubic centimetres. This nectar is completely transparent, very sweet, and slightly mucilaginous. It contained a kind of gum which is precipitated by absolute alcohol. The nectar appears therefore when the anthers have done their work; even an hour before their rupture no trace of it is to be found. The nectarcavity in the tube of the corolla is completely shut up by the numerous spreading hairs at the base of the filaments, so that an outflow is impossible. The grains of pollen are very large $(0.2$ millim. in diameter) and of the same structure as in Cobaa scandens. They are covered by a glutinous layer, and are heavier than water.

Several weeks passed at first before I witnessed the manner of fertilisation. The stigmata were every morning carefully examined, but no pollen could be discovered on them. The filaments twisted back again and got somewhat frizzled, after one single night's expansion. About noon the corolla drops off, separating from close to the glandular ring, and then slipping down over the style, which, by this time, is again in a relaxed hanging position. There is always some nectar in the tube of the corolla after its separation, but none remains in the calyx round the ovary, nor does its secretion continuc.

These facts show clearly that the fertilisation must take place in the same night after the bursting of the anthers, and it was but natural to suppose that it was effected by nozturnal moths. It would appear, furthermore, that the nectar is not of any direct advantage to the plant, as $\mathrm{Mr}$. G. Bonnier emphatically affirms (Annales des Sci. Nat. b'ot., sér. vi. vol. viii. p. 206), because of its bcing produced and lost in all flowers, fertilised or not, in the same way.

As soon as the number of flowers increased (on some evenings twenty to twenty-five had thcir anthers opened), I found every morning most of them with pollen on the stigmata, and kecping a close watch, I discovered that the plant was visited by several large Sphingid $x$ belonging to the genera Chacrocampa, Diludia, and Amphonyx. I observed altogether four visits of an Amphonyx, three of a Chaerocampa, and one of a Diludia. All of them procceded in the same manner. Holding the body close over the style, they dipped their spiral tongues into the tube of the corolla, beating all the while the anthers so violently with the tips of the fore-rings that they dangled about with great velocity in every direction. The grains of pollen being covered by a sticky substance, many of them adhered to the wings. I have causht an Amphonyx which, after having visited six flowers consecutively, had the tips of the fore-wings almost yellow with pollen. When leaving a flower for another one, some of this pollen is even lost on the foliage, but by the time the insect takes its central position before the flower the stigmata are likewise touched by the wings, and thus some pollen is left on them. Some flowers remain without being fertilised, especially in places where the moths cannot reach them easily. All flowers fertilised in this manner set fruit very soon; but no flower gave a fruit without having its stigmata pollenised by crossing.

Self-fertilisation is therefore excluded, and this is further proved by the following experiments :-Twelve flowers were artificially fertilised by their own pollen and afterwards protected by muslin bags; only in one case was a fruit obtained; but I am not quite sure whether there did not come some foreign pollen on the stigmata of this flower. Cross-fertilisation was likewise tried in twelve flowers, nine being experimented on in the same evening after the opening of the anthers, and three the nexi morning. All the former are now with fruit; the latter remained sterile. This fact shows how very short is the period of possible fertilisation.

Flowers visited by nocturnal moths are as a rule either large and of white colour, or have a strong smell; but in our Cobcea the former is certainly not the case, and my olfactory nerves at least cannot discover any smell. But it is well known that insects, especially Lepidoptera, are in this respect of a really wondcrful keenness, which enables them to track a scent absolutely imperceptiblc to man.

As I shall have a considerable crop of Cobra-seeds, I can offer some to any botanists who should wish to grow the plant.

Carácas, April 4

A. ERNST

P.S. - As soon as the corolla has fallen off, the peduncle withdraws slowly amongst the dense foliage, where the fruit develops, protected from all kinds of injury.

\section{EXI'ERIMENTAL RESEARCHES IN} ELECTRICITY $Y^{1}$

Part III.-Tube-Potential; Potential at a Constant Distance and Various Pressures; Nature aud Phenomena of the Electric Arc.

M ESSRS. De La Rue and Müller, in the third part of their rescarches on the electric discharge, commence by describing a series of experiments to determine the potential necessary to produce a discharge in a tube, exhausted gradually more and more while using a constant number of cells in all the experiments. In consequence of the life of the battery becoming so much exhausted by the method employed the experiments were confined to one gaseous medium, namely, hydrogen. Since the completion, however, of the measurements described in the paper the authors have found two other more convenient methods for determining the tube-potential, which do not exhaust the battery injuriously; these are described in an appendix. The tube, 162 , employed was 33 inches long and 2 inches in diameter, the distance between the ring and straight wire terminals being 29.75 inches; the battery consisted of II,, 00 cells. The discharge took place when the pressure was reduced to $35.5 \mathrm{~mm} ., 46,710 \mathrm{M}$ (millionths of an atmosphere), and the exhaustion was afterwards continued gradually until it fell to $0^{\circ} 0065 \mathrm{~mm}$. $8.6 \mathrm{M}$. In commencing each set of experiments the deflection of a tangent-galvanometer was observed when 'the battery was short-circuited. By a table previously calculated the valuc of the deflection in ohms of resistance per cell could

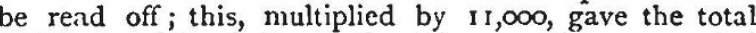
resistance of the battery; the tube was then connected with the terminals and the galvanometer again observed; this gave a less deflection and indicated a greater resistance, which, multiplied by II,, 00 , gave the total resistance of the tube and battery : by subtracting the resistance of the battery the resistance of the tubc was ascertained. Calling the total resistance $\mathrm{R}$, the tube resistance $r$, the tube-potential $\mathrm{V}, \mathrm{V}=\frac{r \times \mathrm{I}, 000}{\mathrm{R}} \cdot$ The tube-potential requisite to produce a discharge, with a pressure of 46,7 Io $\mathrm{M}$, was found to be 10,250 cells; this gradually fell until I "Experimental Rescarches on the F.lectric Discharge with the Chlor.de of Silver Battery," by Warren De La Rue, M.A., D.C.L., F.R.S., and Hugo W. Müiler, Pì.D., F.R.S. (Ihil. Trants., vol. clxxi. [1. 65 ). 